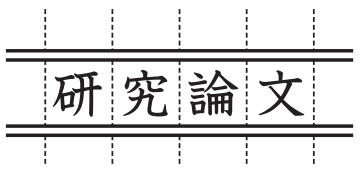

\title{
高温高湿環境下における銅 / エポキシ樹脂界面の劣化寿命評価

\author{
Evaluation of Deterioration Life of Interface of Copper and Epoxy Resin \\ under High Temperature and High Humidity Conditions
}

\author{
戸野塚 悠* ·小林 竜也*・荘司 郁夫* \\ 外薗洋昭**・高橋邦明***・江連＼cjkstart徳**** \\ Yu TONOZUKA, Tatsuya KOBAYASHI, Ikuo SHOHJI, \\ Hiroaki HOKAZONO, Kuniaki TAKAHASHI and Toku EZURE
}

(Received March 30. 2018)

\begin{abstract}
The aim of this study is to investigate degradation behaviors of the adhesion strength of the Cu/resin (bisphenol F-type epoxy resin) interface in soaking under high humidity and high temperature conditions. Thermal humidity tests and highly-accelerated temperature and humidity stress tests (HAST) were conducted and the adhesion strength was investigated by a tensile test. An airHAST was also conducted for a comparison. The fracture surface was analyzed by Fourier transform infrared spectroscopy (FTIR) to investigate the degradation mechanism of the adhesion strength. As a result, it was found that the adhesion strength decreases according to soaking and its degradation increases with increasing soaking temperature. Also, the degradation in the HAST is larger than that in the air-HAST. Degree of water absorption in the $\mathrm{Cu} / \mathrm{resin}$ interface $\left(D_{\mathrm{w}}\right)$, which was defined by the results of FTIR analysis, tends to rapidly increase in early period of soaking and saturate afterwards. Even after absorbing water in the resin by soaking saturated, water infiltrating in the $\mathrm{Cu} / \mathrm{resin}$ interface induced the formation of copper oxide and caused a further degradation of the adhesion strength. From the Arrhenius plot of the deterioration life of the adhesion strength which was determined by $D_{\mathrm{w}}$, different tendencies were found in the regions before and after the glass transition temperature of the resin. Thus it was suggested that the life prediction equation for each region is required.
\end{abstract}

Key Words: Epoxy Resin, Cu, Adhesion, Thermal Humidity Test, HAST, Water Absorption

\section{1. 緒言}

近年、電気自動車や産業用機器への適用のため $\mathrm{SiC} や ~$ $\mathrm{GaN}$ 等のワイドバンドギャップ半導体の開発が進展してい る。ワイドバンドギャップ半導体はバンドギャップが広く、 熱伝導に優れることから耐電圧に優れ、高温動作が可能で ある1)。それらの半導体を用いるパワーモジュールは様々な 分野への応用が期待されており、使用環境の拡大に向け小 型化、高機能化の研究が行われている2)。しかし、製品の小 型化に伴う高密度化および高電圧化により、今後パワーモ ジュール用の半導体素子はパワーサイクル負荷時の最高温 度が $200{ }^{\circ} \mathrm{C}$ を超えることが予想されている3),4)。また、さら なる過酷な環境での使用には、温度変化や外部衝撃に耐え られる構造にする必要がある。そのため、モジュールのパッ ケージには高耐熱性、放熱性、耐衝撃性といった機能が求 められる5),6)。これらの問題を解決すべく、モジュールに対
して樹脂封止によるパッケージが施される7)。しかし、パ ワーモジュールは使用時に高温になり、かつ長期にわたり 使用されるため、基板と封止樹脂の接着界面の劣化が懸念 される。また、金属/樹脂界面は熱や湿度による影響を受 けやすいため、樹脂同士、金属同士の接合強度よりも非常 に弱くなる。そのため、基板に用いられる金属と樹脂の接 着強度と高温高湿での劣化挙動の検討が、パワーモジュー ルの高信頼性化には極めて重要となる。

そこで本研究では、銅と封止樹脂に使用されるビスフェ ノール F 型エポキシ樹脂の接着部を研究対象として、高温 高湿時効による銅 / 樹脂界面の劣化挙動を引張試験にて調 査し、界面の寿命評価を試みた。

\section{2. 実験方法}

\section{1 供試材}

本研究で使用した樹脂材 (ガラス転移温度 $T_{\mathrm{g}}: 106.2^{\circ} \mathrm{C}$ )

* 群馬大学大学院理工学府知能機械創製部門（率 376-8515 群馬県桐生市天神町 1-5-1）

Division of Mechanical Science and Technology, Gunma University (1-5-1, Tenjin-cho, Kiryu, Gunma 376-8515, Japan)

* *富士電機株式会社（） 191-8502 東京都日野市富士町 1 番地）

Fuji Electric Co., Ltd.（1, Fuji-machi, Hino 191-8502, Japan)

***株式会社産業分析センター（～340-0028 埼玉県草加市谷塚二丁目 11 番 7 号）

The Industrial Analysis Service Ltd. (2-11-7, Yatsuka, Soka, Saitama 340-0028, Japan

****エエスペック株式会社（～３21-3231 栃木県宇都宮市清原工業団地 23-1）

ESPEC Corp. (23-1, Kiyohara Kogyodanchi, Utsunomiya, Tochigi 321-3231, Japan) 
Table 1 Specification of resin material.

\begin{tabular}{|c|c|}
\hline Structural components & [wt ratio] \\
\hline Bisphenol F diglycidyl ether & 100 \\
\hline Bis (4-amino-3-ethylphenyl) methane & 40 \\
\hline
\end{tabular}

Table 2 Chemical compositions of $\mathrm{Cu}$ rivet.

\begin{tabular}{|c|c|c|c|c|c|c|}
\hline \multicolumn{7}{|c|}{ Chemical compositions [mass\%] } \\
\hline As & $\mathrm{Sb}$ & $\mathrm{Bi}$ & $\mathrm{Pb}$ & $\mathrm{S}$ & $\mathrm{Fe}$ & $\mathrm{Cu}$ \\
\hline$<0.0002$ & $<0.0001$ & 0.00002 & 0.0004 & $<0.0010$ & 0.0003 & Bal. \\
\hline
\end{tabular}

の仕様を Table 1 に示す。ビスフェノール F ジグリシジル エーテルおよびビス (-4- アミノ -3- エチルフェニル)メタン をそれぞれマトリクス樹脂および硬化剤として使用し、そ れらを混錬した後、室温で減圧 $70 \mathrm{~Pa} 、 2 \mathrm{~h}$ の脱泡処理を施 した。銅材にはリベット(シャフト部径、ヘッド部径、リベッ 卜高さがそれぞれ 2.0、4.0、3.0 mm）を用いた。その組成を Table 2 に示す。銅材に対し、樹脂の塗布面を\#1000 の耐 水研磨紙で研磨した後、 $150^{\circ} \mathrm{C} 、 60 \mathrm{~min}+60{ }^{\circ} \mathrm{C} 、 60 \mathrm{~min}$ の 条件で酸化処理を施した。

\section{2 試料作製方法㧍よび実験方法}

銅/樹脂接合体の作製は、ステージ温度を $150^{\circ} \mathrm{C}$ に設定 した継手強度試験機 (レスカ製 STR-1000)を用いて行った。 2 つの銅リベット (接着部径: $\phi 2.0 \mathrm{~mm}$ )を向かい合わせて リベット間の間隙を $0.1 \mathrm{~mm}$ に固定し、間隙部に樹脂を塗 布した。その後、ステージ上で $150^{\circ} \mathrm{C} に て ~ 2 \mathrm{~h}$ 加熱するこ とで樹脂を仮硬化させ、加熱炉内にて更に $150{ }^{\circ} \mathrm{C} に て ~ 2 h$ 加熱することで完全硬化させた。作製した銅/樹脂接合体 の外観を Fig. 1 に示す。

作製した試験片に対して時効処理を 4 条件： $85^{\circ} \mathrm{C} 、 85 \%$ R.H. での Thermal Humidity Test (THT)、 $110{ }^{\circ} \mathrm{C} 、 85 \%$ R.H. で ๑) Highly-Accelerated Temperature and Humidity Stress Test (HAST)、 $130^{\circ} \mathrm{C} 、 85 \%$ R.H. で の HAST、 $110^{\circ} \mathrm{C} 、 85 \%$ R.H. での Air-HASTを実施した。HAST は、電子機器関連 の加速性を伴う耐湿性評価法として、JIS C 60068-2-66 ${ }^{8}$ で 規定されている。該当規格は IEC 60068-2-66, Environmental testing - Part2: Test methods - Test Cx: Damp heat, steady state (unsaturated pressurized vapour)の翻訳版であり、相対湿度 は $85 \%$ R.H.、温度は $110^{\circ} \mathrm{C} 、 120^{\circ} \mathrm{C}$ および $130^{\circ} \mathrm{C}$ の 3 条件 に規定される。本研究では、銅/樹脂界面の劣化挙動に及 ぼす温度の影響を調查するために、THT の $85^{\circ} \mathrm{C}$ も考慮し、 HAST の温度は $110^{\circ} \mathrm{C}$ および $130^{\circ} \mathrm{C}$ の条件とした。処理時 間は 100、250、500、750、1000 h とし、時効処理を施さ ないものについても評価した。Table 3 に試験条件拈よび 試験時の試験槽内の絶対圧の関係を示す。Air-HAST は、槽 内に空気を残留させた状態で試験が実施される9。本研究

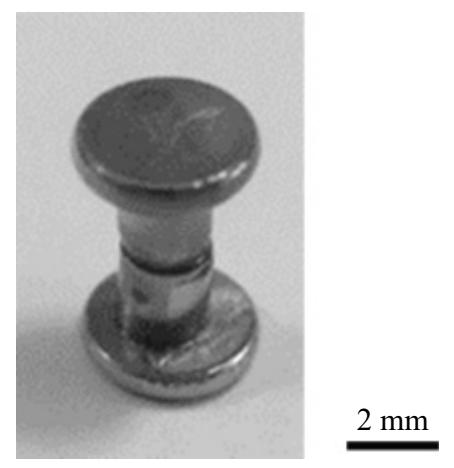

Fig. 1 General view of $\mathrm{Cu} / \mathrm{Cu}$ joint with resin.

Table 3 Test conditions and absolute pressures.

\begin{tabular}{|c|c|}
\hline $\begin{array}{c}\text { High Humidity and High } \\
\text { Temperature Conditions }\end{array}$ & Absolute Pressure [MPa] \\
\hline $85^{\circ} \mathrm{C}, 85 \%$ R.H. THT & 0.1013 \\
\hline $110^{\circ} \mathrm{C}, 85 \%$ R.H. HAST & 0.1218 \\
\hline $130^{\circ} \mathrm{C}, 85 \%$ R.H. HAST & 0.2296 \\
\hline $110^{\circ} \mathrm{C}, 85 \%$ R.H. Air-HAST & 0.2498 \\
\hline
\end{tabular}

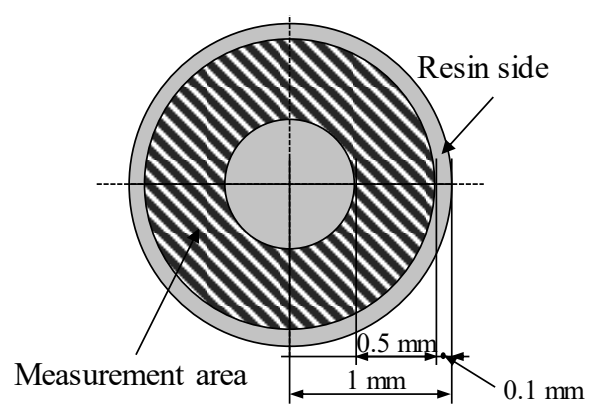

Fig. 2 Image of measurement area for IR spectrum.

では、界面に対する空気と水の混合気体の影響を調査し、 HAST と Air-HAST の比較を行った。な拉、本研究で使用し

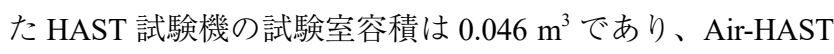
試験開始時にはその容積に相当する空気が入っていた。

時効処理後、引張試験を引張速度 $0.1 \mathrm{~mm} / \mathrm{s}$ にて行い、 CCD スコープによる破面観察と Fourier Transform Infrared Spectroscopy (FT-IR) による樹脂材の化学構造解析を行っ た。解析は、破断部の樹脂付着面を、Attenuated Total Reflection (ATR) 法にて、分解能: $8 \mathrm{~cm}^{-1}$ の条件で実施した。 IR スペクトルの測定領域を Fig. 2 に示す。高温高湿の影響 は接合部の外周から発生することが予想されるため、測定 を破面外周部に限定した。本研究では、引張試験後の破面 の端部にて凝集破壊が顥著に確認された。そのため、界面 破壊した領域を評価対象とするために、凝集破壊の発生し やすかった破面端部での測定を避けた。測定に使用したア パーチャーサイズが $0.1 \times 0.1 \mathrm{~mm}^{2}$ であったため、Fig. 2 の 斜線で示した測定領域において界面破壞が生じた領域の残 
存樹脂部に対して、任意の 3 点について測定範囲 : $0.1 \times 0.1$ $\mathrm{mm}^{2}$ で測定を実施した。

\section{3. 実験結果および考察}

3.1 銅 / 樹脂接合体の引張強度に及ぼす高温高湿環境の影響 銅 / 樹脂接合体の引張試験により得られた引張強度と時 効時間の関係について、Fig. 3 および Fig. 4 に示す。なお、 図中には測定点より求めた近似曲線も併記している。全て の時効条件において時効時間の増加に伴い、引張強度の低 下が確認された。また、Fig. 3 より温度上昇に伴い引張強 度の低下が大きくなることがわかる。さらに、Fig. 4 より $110^{\circ} \mathrm{C} 、 85 \%$ R.H. の条件では Air-HAST よりも HAST の方 が引張強度の低下が大きいことがわかる。

\section{2 破面観察結果}

Fig. 5 に各時効条件における引張試験後の破面観察結果 を示す。図より、全ての時効条件において接合体の破壊 は、ほとんどが銅/樹脂の界面で発生しており、界面破壞 の領域では、一方の破面に樹脂が残り、もう一方の破面に は銅が露出することが確認された。モノクロモードで示し た Fig. 5 においては銅と樹脂の識別は難しいが、元図であ

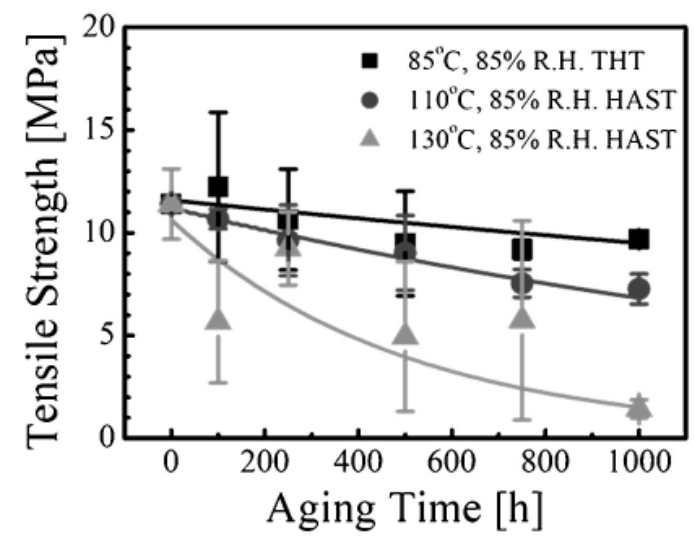

Fig. 3 Effect of aging temperature on tensile strength of $\mathrm{Cu} / \mathrm{Cu}$ joint with resin.

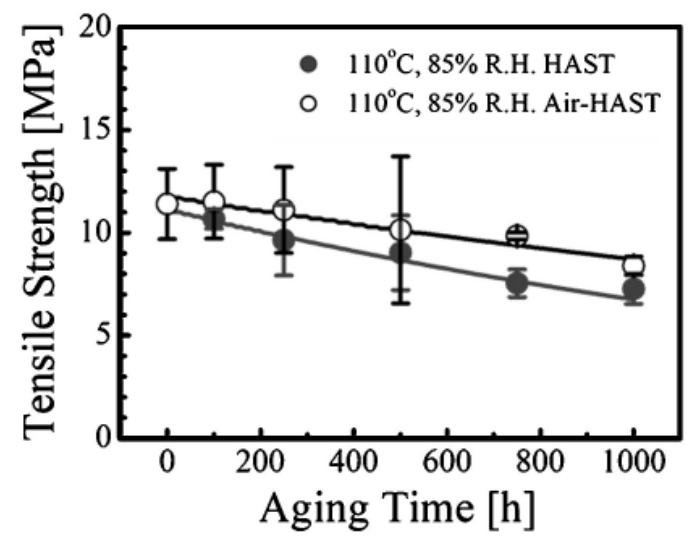

Fig. 4 Comparison of HAST and Air-HAST in tensile strength of $\mathrm{Cu} / \mathrm{Cu}$ joint with resin.
るカラーモードの CCD スコープ像より、図の “Resin side” では、図中に付記したように变色等は見られるもののすべ ての領域で樹脂の残存が見られた。本研究では、破断部の 両方のリベットに樹脂が残存した領域の面積をリベットの 面積で除した值を凝集破壊率として評価した。凝集破壊率 と時効時間の関係を、Fig. 6 およびFig. 7 に示す。両図より、 凝集破壊率は全ての条件において $15 \%$ 以下となることが確 認された。このことから、銅/樹脂接合体の引張強度は銅 / 樹脂界面の接着強度に強く依存することが明らかとなっ た。さらに、Fig. 5 の破面観察結果から、時効時間が増加 すると銅の外周部が変色し、時効温度が高いほど $1000 \mathrm{~h}$ 時 効後の接合面の銅の変色領域が大きくなることが確認され た。以上より、銅/樹脂接着界面の劣化は、高温高湿に曝 される外周から発生することが示唆された。また、Fig. 5 より HAST と Air-HASTの樹脂側破面を比較すると、AirHAST では樹脂の外周部の変色が確認された。Fig. 5 (b) の Air-HASTにおいて銅側の変色域に相対する樹脂側破面の 樹脂が黒色に変化していた。よって、Air-HAST 条件では 熱分解による樹脂自身の劣化も進行していることが考えら れる ${ }^{10)}$ 。

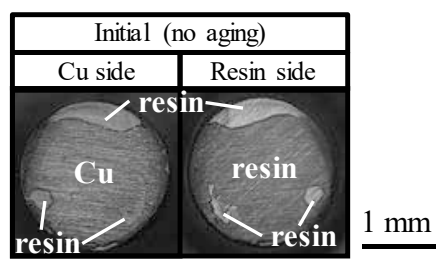

(a)

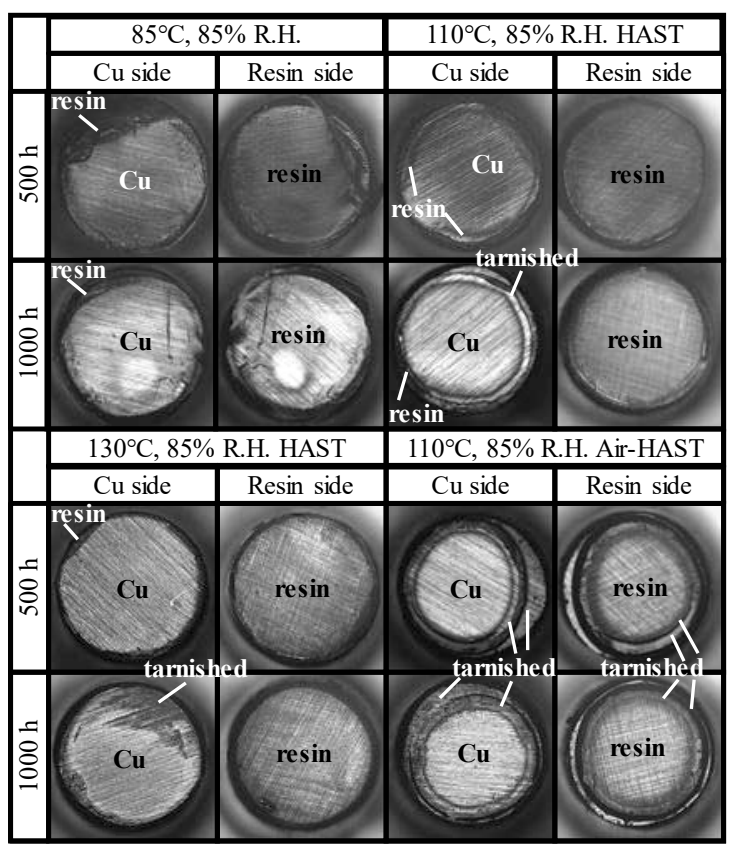

(b)

Fig. 5 General views of fractured specimens after tensile test by CCD scope. (a) before aging. (b) after aging. 


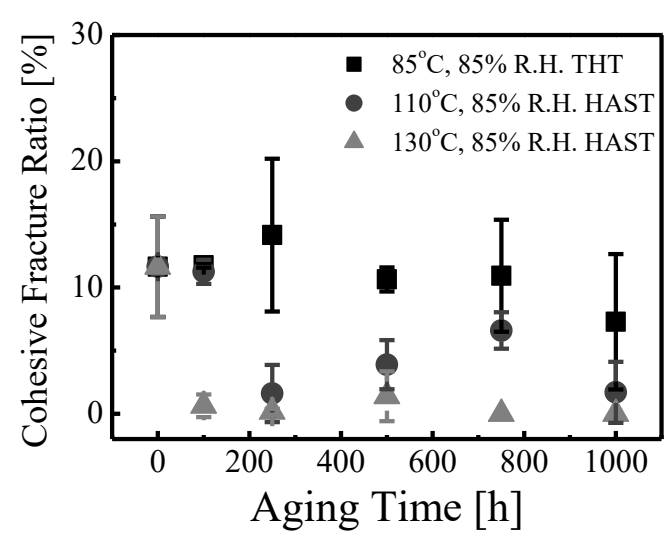

Fig. 6 Effect of aging temperature on cohesive fracture ratio of $\mathrm{Cu} / \mathrm{Cu}$ joint with resin.

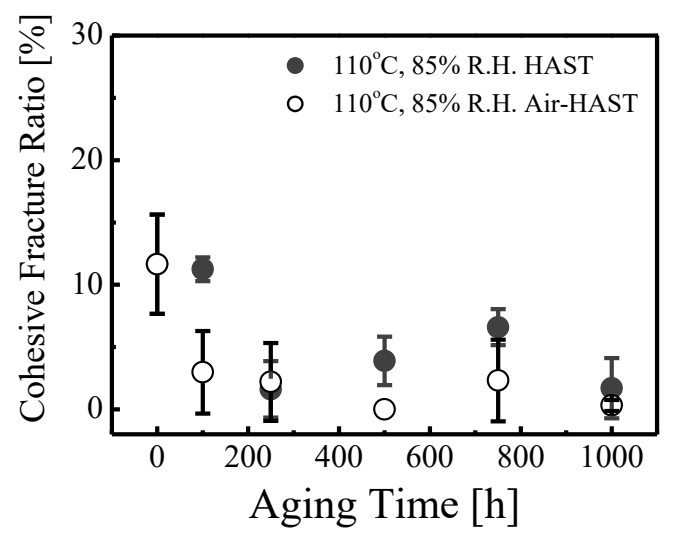

Fig. 7 Comparison of HAST and Air-HAST in cohesive fracture ratio of $\mathrm{Cu} / \mathrm{Cu}$ joint with resin.

\subsection{FT-IR 解析結果}

樹脂側破面の FT-IR の解析結果について、条件 $110^{\circ} \mathrm{C}$ 、 $85 \%$ R.H. HAST を例に測定範囲 $1500-1250 \mathrm{~cm}^{-1}$ の結果を Fig. 8 に示す。時効時間の増加に伴いアミン基の変角振動 由来のピーク強度 (N-H: $\left.1296 \mathrm{~cm}^{-1}\right)$ の減少が全ての条件に おいて確認された。樹脂は高温高湿環境下に曝されること で吸水を引き起こす。この吸水反応により水と反応するア ミン基のピーク強度の減少が発生したと推察される。本研 究では、銅/樹脂界面での吸水反応によって結合の脆弱化 が生じ、Fig. 3 及びFig. 4 に示したような時効に伴う強度 低下が発生したものと考えられる。一般に、樹脂は機械的 結合や化学的結合により金属と接着する。機械的結合は樹 脂が金属の微細な凹凸に入り达んで硬化し、アンカー効果 を引き起こすことで得られ、化学的結合は樹脂が金属表面 の酸化被膜と界面で水素結合を形成することで得られる。 吸水反応により樹脂が膨張すると、銅との熱膨張差によっ て接着界面に局所的剥離が生じ、接着力が低下すると考え られる。また、水素結合には界面での水分子の存在が必要 不可欠となるが、吸水反応により銅/樹脂接着界面に水分

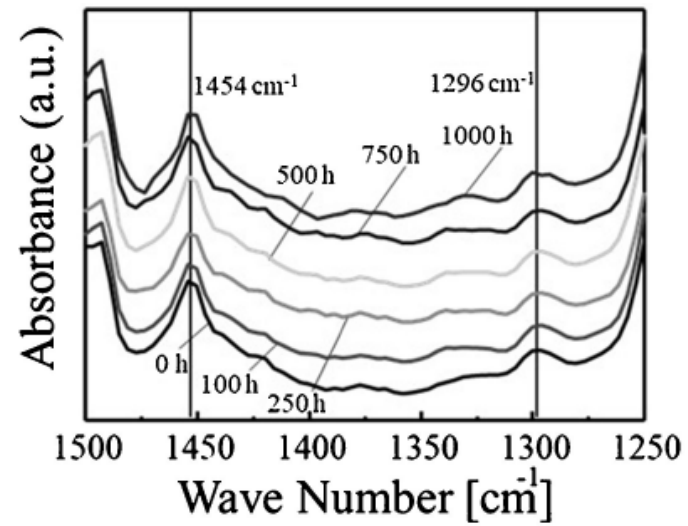

Fig. 8 Effect of aging treatment of $\mathrm{Cu} / \mathrm{Cu}$ joint with resin on IR spectrum from $1500 \mathrm{~cm}^{-1}$ to $1250 \mathrm{~cm}^{-1}\left(110^{\circ} \mathrm{C}, 85 \%\right.$ R.H. HAST).

が多量に入り込むと、水素結合の脆弱化が生じることが示 唆された。以上より、機械的および化学的結合に吸水反応 が作用することで接着強度が低下したと考えられる。

芳香族の伸縮振動に由来するピーク強度 $(\mathrm{C}=\mathrm{C}: 1454$ $\left.\mathrm{cm}^{-1}\right)$ は非常に強固な結合であるため、高温高湿の影響を 受けにくい。そこで本研究では、芳香族とアミン基のピー ク強度比を算出することでアミン基のピーク強度を定量化 し、時効後のピーク強度比と時効前のピーク強度比の差を 求めることで (1) 式に示す吸水度合い $D_{w}$ を定義した。ここ で、ピーク強度比の差に着目したのは、構造用エポキシ系

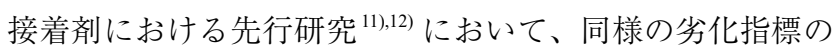
有効性が示唆されたことによる。

$$
D_{w}=\frac{I_{b}}{I_{a}}-\frac{I_{b 0}}{I_{a 0}}
$$

$D_{w}$ : 吸水度合い

$I_{a}:$ 時効後のアミン基のピーク強度

$I_{b}:$ 時効後の芳香族のピーク強度

$I_{a 0}:$ 時効前のアミン基のピーク強度

$I_{b 0}:$ 時効前の芳香族のピーク強度

吸水度合いと時効時間の関係を Fig. 9 および Fig. 10 に示 す。図中の曲線は、後述するように、強度劣化寿命の指標 して $D_{w}$ を使用するために、良好なフィッティングが見ら れた sigmoid 曲線で表している。Fig. 9 およびFig. 10 よ、 吸水度合いは、時効初期段階では急激に増加し、その後、 時効時間 $750 \mathrm{~h}$ 以降は Air-HAST を除く全ての条件で、飽 和する傾向が見られた。この結果は、樹脂の界面における 水の拡散に関する Fick の第二法則に基づく吸水時間と濃度 の関係に類似している ${ }^{13)}$ 。高温環境下におけるエポキシ樹 脂の吸水率は、限定領域では Fick 則に一致することが報告 されているが 14),15)、厳密には、Fick則に従う水分子の物理 的空間への移動とその後の化学結合による体積変化の 2 段 階の解析が必要となる ${ }^{13)}$ 。本研究の樹脂材に関しては、単 


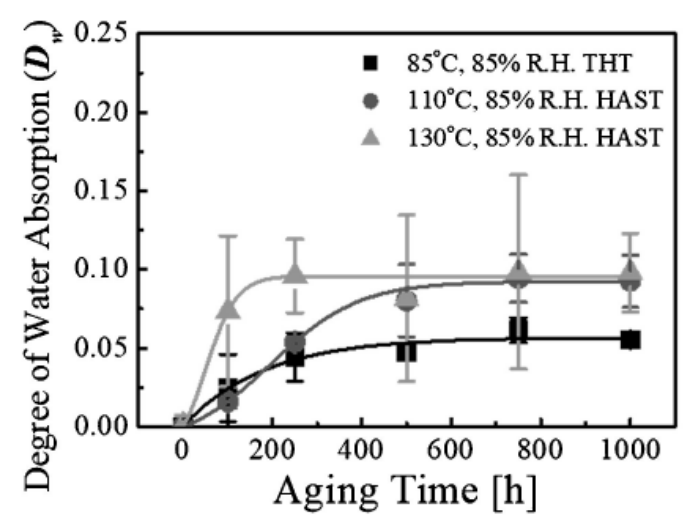

Fig. 9 Change in degree of water absorption of $\mathrm{Cu} / \mathrm{Cu}$ joint with resin.

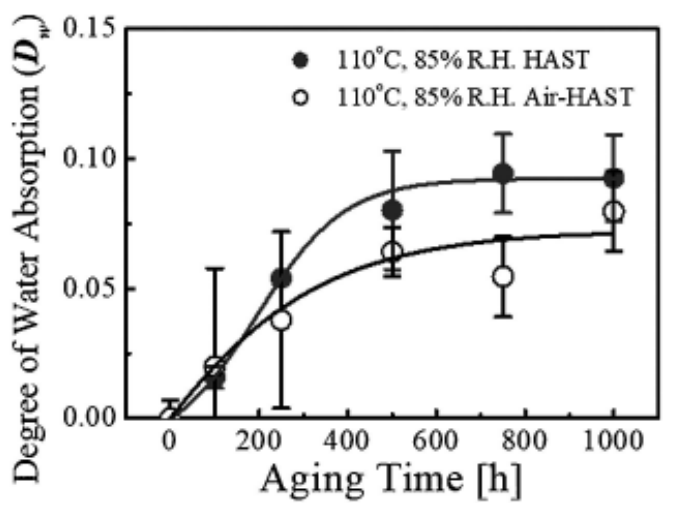

Fig. 10 Comparison of HAST and Air-HAST in degree of water absorption.

純な吸水率の評価結果がないため、同様の解析は今後の検 討課題である。

Fig. 9 より時効温度が高いほど、時効初期段階の吸水度 合いの増加量が大きくなることがわかる。本研究に用いた 樹脂は $T_{\mathrm{g}}$ が $106.2^{\circ} \mathrm{C}$ であり、試験温度域が $T_{\mathrm{g}}$ を跨ぐため、 $T_{\mathrm{g}}$ 以上の温度となる $130{ }^{\circ} \mathrm{C}$ では樹脂の分子運動の活発化に より吸水が促進されたと考えられる。また、Fig. 10 より Air-HAST はHAST と比較して吸水の進行が緩やかである ことが確認された。Air-HAST槽内に充填された空気により、 HAST 試験に比べ吸水反応が阻害されたものと考えられる。

Fig. 11 および Fig. 12 に吸水度合いと引張強度の関係を 示す。図中には、 $130{ }^{\circ} \mathrm{C} 、 85 \%$ R.H. での HAST を除き、各 試験のデータより得られた回帰直線も示した。Fig. 11より、 $85^{\circ} \mathrm{C} 、 85 \%$ R.H. での THT および $110^{\circ} \mathrm{C} 、 85 \%$ R.H. での HAST、 $110^{\circ} \mathrm{C} 、 85 \%$ R.H. での Air-HAST では、吸水度合 いの増加に伴い引張強度が直線的に減少することが確認さ れた。一方、 $130{ }^{\circ} \mathrm{C} 、 85 \%$ R.H. での HAST では、吸水度合 いの飽和後も更なる引張強度の低下が確認された。Fig. 5 の破面観察結果から、樹脂の吸水が飽和状態になった後も 銅表面の劣化等から、さらに強度低下が発生したと推察さ れる。銅表面の劣化要因として、酸化膜の成長、粗化が考

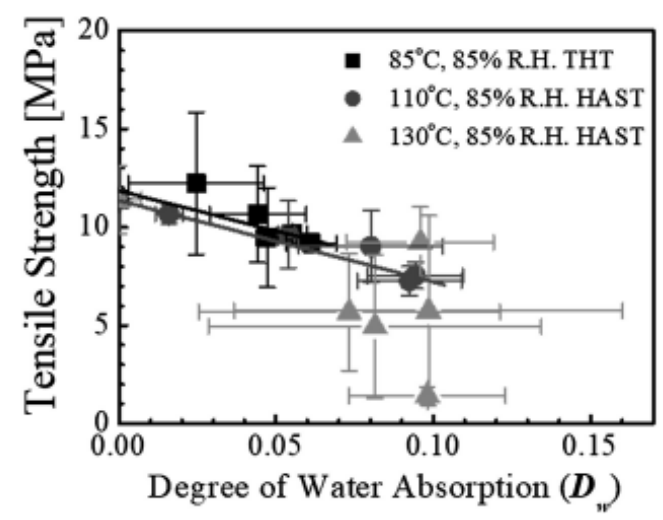

Fig. 11 Relationship between tensile strength and degree of water absorption under deferent aging conditions.

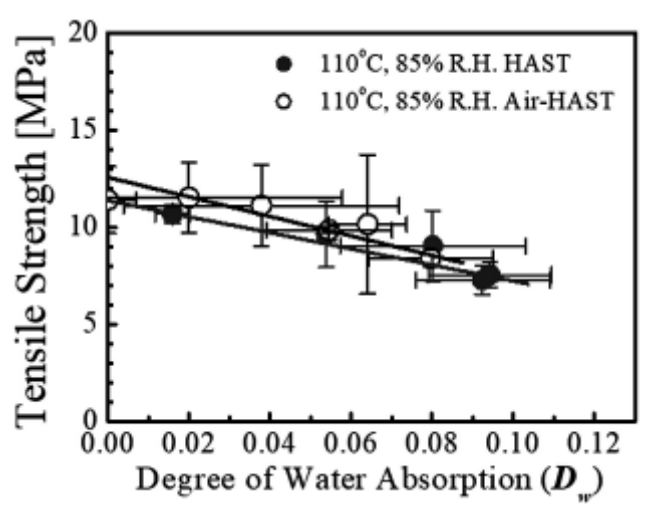

Fig. 12 Relationship between tensile strength and degree of water absorption in HAST and Air-HAST.

えられる。樹脂の吸水による体積膨張に伴い、銅/樹脂界 面には水が浸入するのに十分な空間が発生すると考えられ る。銅が水と酸化反応を引き起こすために、 $130{ }^{\circ} \mathrm{C} 、 85 \%$ R.H. での HAST における時効時間 $1000 \mathrm{~h}$ 条件においては、 Fig. 5 に示したように、銅表面が局所的に黒色へ変化した と考えられる。銅に形成される黒色酸化物は、層構造が密 ではなく機械的性質が弱いためエポキシ樹脂等の有機材料 と接着不良を引き起こすことが知られている ${ }^{16}$ 。そのため、 高温条件において接合体の強度が急激に低下したと考えら れる。

\section{4. 銅 / 樹脂界面の寿命評価}

Dakin が化学反応速度の立場から提案した寿命予測方法 を基に、銅/樹脂接合体の劣化寿命について評価した ${ }^{17)}$ 。 一般に化学反応速度は反応物質の時間による濃度変化に よって式(2)のように表される。

$$
\begin{gathered}
-\frac{d c}{d t}=k c^{n} \\
k=A^{\prime} \exp \left(-\frac{E}{R T}\right)
\end{gathered}
$$


$c$ : 反応物質の濃度 $t$ : 時間 $k$ : 反応速度定数

$n$ : 反応次数 $A^{\prime}:$ 頻度因子

$E:$ みかけの活性化エネルギー

$R$ : 気体定数 $\left(8.314 \mathrm{~J} \cdot \mathrm{K}^{-1} \mathrm{~mol}^{-1}\right) \quad T$ : 絶対温度 $(\mathrm{K})$

ここで、強度等の特性值の低下は化学反応の結果である と考えて、特性值 $p$ を濃度 $c$ と同様に扱えると仮定して $c=$ $p$ とおく。化学反応を 1 次反応 $(n=1)$ として $\ln p$ を解き、(3) 式を用いて $\ln t$ を解くと式 (4) が求まる。

$$
\ln t=\ln \left(\frac{1}{A^{\prime}} \cdot \ln \frac{p_{0}}{p}\right)+\frac{E}{R T}
$$

\section{$P_{0}:$ 反応前の $P$}

故に、 $p$ がある一定值 $p$ に低下するまでの時間 $t$ を寿命 $L$ とすると式 (5) が得られる。

$$
\ln L=\ln A+\frac{E}{R T}
$$

\section{$A$ : 頻度因子 $L:$ 寿命}

したがって、 $\ln L$ と $1 / T$ の直線関係を利用すれば、時効 試験結果を外挿して、使用温度における寿命を推定するこ とが可能となる。

本研究では、FT-IR 解析で得られた結果から、吸水度合 い $D_{w} \doteqdot 0.1$ を飽和吸水度合いと定義し、飽和吸水度合いの $50 \%$ に相当する、 $D_{w}=0.05$ に達した際の時間を銅 / 樹脂界 面の強度劣化寿命 $L$ と定義することで接合体の劣化寿命を 評価した。本研究では、 $L$ と $D_{w}$ の関係は Fig. 9 および Fig. 10 の各試験におけるデータより導出される回帰曲線によっ て求められる。本研究では、それらの回帰曲線を(6) 式に 示す Boltzmann 関数により sigmoid 曲線として導出した。

$$
D_{w}=\frac{A_{1}-A_{2}}{1+\exp \left(\frac{t-t_{0}}{d t}\right)}+A_{2}
$$

$A_{1}$ : 初期值

$A_{2}:$ 最終值

$t_{0}:$ センター值

$A_{1} 、 A_{2} 、 t_{0}$ に関して、Fig. 9 およびFig. 10 に示した吸 水度合いの傾向と限りなく一致するよう入力值を求めた。 Table 4 に各条件における入力值と寄与率 $\mathrm{R}^{2}$ を示す。寄与 率が全ての条件において $98 \%$ 以上であることから曲線式の 一致性が確認され、 $L$ と $D_{w}$ の関係を求める際に、導出した 回帰曲線が有用となることが示された。

Fig. 13 に $L$ の アレニウスプロット結果を示す。Fig. 13 よ、アレニウスプロットは $T_{\mathrm{g}}$ 付近を境にして多少異 なる傾向を示すため、一つの直線で回帰することは困難で あることが確認された。これは $3.3 て ゙$ 述べた吸水現象での
考察と同様に、試験温度が $T_{\mathrm{g}}\left(106.2^{\circ} \mathrm{C}\right)$ を超えると分子運 動が活発化し、吸水反応速度に影響を及ぼすためと考えら れる。 $T_{\mathrm{g}}$ 以上の高温域である $130{ }^{\circ} \mathrm{C} 、 85 \%$ R.H. HAST では 接合体界面の吸水による劣化が速いため、寿命が低温度域 と比較して短い。また、 $T_{\mathrm{g}}$ 前後の温度域でみかけの活性化 エネルギーの評価を試みたところ、85-110 ${ }^{\circ} \mathrm{C} 、 85 \%$ R.H. お よび $110-130{ }^{\circ} \mathrm{C} 、 85 \%$ R.H. の試験条件において、それぞれ 41.07 および $75.63 \mathrm{~kJ} / \mathrm{mol}$ となった。測定点が少なく、今後 継続して、両領域におけるデータを追加して評価を行う必 要があるが、 $T_{\mathrm{g}}$ 前後の温度領域において、それぞれに有効 な寿命評価式を構築する必要が示唆された。

Table 5 に $D_{w}=0.05$ の場合の各条件における引張強度 $T_{\mathrm{D}}$ と、時効前の引張強度を $100 \%$ とした場合の相対強度比を 示す。Table 5 より試験温度の増加に伴い、 $T_{\mathrm{D}}$ が減少する ことがわかる。Fig. 9 に示したように、吸水度合いは時効 初期に急激な増加を示し、その後飽和する傾向がみられる。 その傾向は温度が高いほど大きくなるため、時効初期に吸 水度合いが急増する $130^{\circ} \mathrm{C} 、 85 \%$ R.H. HAST では、相対強 度は著しく低くなった。Fig. 13 に示したように、本研究 の銅 / 樹脂界面の吸水による強度劣化寿命の温度依存性は、 $T_{\mathrm{g}}$ 付近の温度を境に変化することが明らかになった。本研 究では、時効時間と吸水度合いの関係を Boltzmann 関数に よって導出したが、時効初期段階に発生する高速拡散相お よび時効終期に発生する低速拡散相をより正確に捉えるに は更なる研究が必要と考える。本研究では、飽和吸水度合 いの $50 \%$ に相当する、 $D_{w}=0.05$ を銅 / 樹脂界面の強度劣化

Table 4 Parameters of Boltzmann function in data shown in Figs. 9 and 10.

\begin{tabular}{|c|c|c|c|c|}
\hline $\begin{array}{c}\text { High Humidity and High } \\
\text { Temperature Conditions }\end{array}$ & $A_{1}$ & $A_{2}$ & $t_{0}[\mathrm{~h}]$ & $\mathrm{R}^{2}$ \\
\hline $85^{\circ} \mathrm{C}, 85 \%$ R.H. THT & -0.36048 & 0.05718 & -454.26 & 0.9919 \\
\hline $110^{\circ} \mathrm{C}, 85 \%$ R.H. HAST & -0.01248 & 0.09227 & 196.49 & 0.9995 \\
\hline $130^{\circ} \mathrm{C}, 85 \%$ R.H. HAST & -0.05470 & 0.09687 & 25.269 & 0.9957 \\
\hline $110^{\circ} \mathrm{C}, 85 \%$ R.H. Air-HAST & -0.06692 & 0.07109 & 11.026 & 0.9834 \\
\hline
\end{tabular}

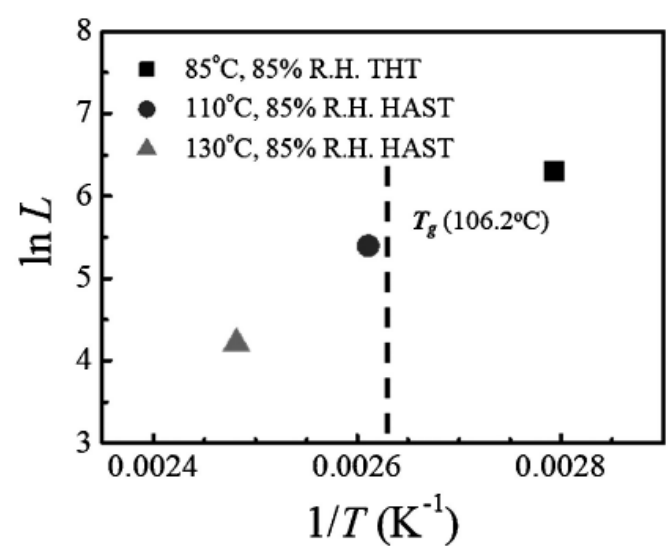

Fig. 13 Arrhenius plot of $\ln L$. 
Table 5 Tensile strength at lifetime $\left(T_{\mathrm{D}}\right)$ and relative strength ratio.

\begin{tabular}{|c|c|c|}
\hline $\begin{array}{c}\text { High Humidity and High } \\
\text { Temperature Conditions }\end{array}$ & $\begin{array}{c}T_{\mathrm{D}} \\
{[\mathrm{MPa}]}\end{array}$ & $\begin{array}{c}\text { Relative Strength } \\
\text { Ratio [\%] }\end{array}$ \\
\hline $85^{\circ} \mathrm{C}, 85 \%$ R.H. THT & 9.74 & 85.4 \\
\hline $110^{\circ} \mathrm{C}, 85 \%$ R.H. HAST & 9.29 & 81.4 \\
\hline $130^{\circ} \mathrm{C}, 85 \%$ R.H. HAST & 6.50 & 57.0 \\
\hline
\end{tabular}

寿命と定義することで接合体の劣化寿命を評価した。しか しながら、Table 5 にみられるように界面強度の低下率は $14.6 \sim 43 \%$ と幅が広く、寿命の定義として高精度な検討に は至らなかった。樹脂中の水の拡散は前述したように Fick の第二法則に基づく吸水現象を示す。そのため、銅/樹脂 界面での吸水を加味した拡散のモデルの構築が必要であ り、界面強度と樹脂中の水の拡散係数との関係性や銅界面 の劣化に関する調査が今後の課題として挙げられる。

\section{5. 結 論}

本研究では銅とエポキシ樹脂の接着部を研究対象とし て、高温高湿時効による銅/樹脂界面の強度低下について 調査した。さらに、強度劣化寿命の温度依存性を調査する ために、強度劣化の要因となる吸水度合いパラメーターを 導入して、アレニウスモデルにて検討を行った。得られた 成果を以下に示す。

1）高温高湿時効により、銅/樹脂接合体の引張強度は低下 する。また、時効温度の増加に伴い、引張強度の低下 が大きくなり、Air-HAST 条件よりも HAST 条件の方が 引張強度の低下が大きい。

2）FT-IR 解析より定義した銅/樹脂界面における樹脂の吸 水度合いは、時効初期において急激に増加し、その後 飽和する傾向を示す。

3）時効により樹脂の吸水が飽和した後も銅/樹脂界面に水 が浸入することで銅が黒色酸化物を形成し、接着強度 の更なる低下を引き起こす。

4）銅 / 樹脂界面の強度劣化寿命を樹脂の吸水度合いより定 義しアレニウスプロットしたところ、 $T_{\mathrm{g}}$ 前後の領域に おいて異なる傾向が見られ、それぞれの領域における 寿命予測式の必要性が示唆された。

\section{謝 辞}

本研究の成果の一部は国立研究開発法人新エネルギー・ 産業技術総合開発機構 (NEDO)の助成事業の補助を受け た。関係各位に謝意を表します。

\section{参考文献}

1）高橋良和、藤平龍彦、宝泉徹：“パワー半導体の現状と展望”、
富士電機技報、87 (2014) 234-239.

2) 春日亮: “パッケージ技術動向”、エレクトロニクス実装学会誌、 10 (2007) 353-357.

3) 菅沼克昭 監修、中西政隆：“次世代パワー半導体実装の要素 技術と信頼性”、シーエムシー出版、(2016) 94-102.

4) 平塚大祐、佐々木陽光、井口知洋: “パワー半導体の高温動 作を可能にするダイボンド材料及び焼結接合技術”、東芝レ ビュー、70 (2015) 46-49.

5) S. G. Hong, T. C. Wang: "Effect of copper oxides on the thermal oxidative degradation of the epoxy resin", Journal of Applied Polymer Science, 52 (1994) 1339-1351.

6) N. Y. A. Shammas: "Present problems of power module packaging technology", Microelectronics Reliability, 43 (2003) 519-527.

7) 梨子田典弘、日向裕一郎、堀尾真史: “All-SiC モジュール技術”、 富士電機技報、85 (2012) 403-407.

8) JIS C 60068-2-66:2001 環境試験方法 - 電気 - 電子 - 高温高湿、 定常 (不飽和加圧水蒸気) (2001)

9) 鈴木聡、棚橋紀悟、土井卓也、増田淳: “結晶 $\mathrm{Si}$ 太陽電池モジュー ルにおける高温高湿試験の加速方法の検討”、エレクトロニク ス実装学会誌、18 (2015) 226-234.

10) Y. Tonozuka, I. Shohji, S. Koyama and H. Hokazono: "Degradation behavior of adhesion strength between epoxy resin and copper under aging at high temperature", Procedia Engineering, 184 (2017) 648654.

11）承室雄也、定井麻子、松井恵子、住田弘祐、山本研一：“ウェ ルドボンド用接着剂の市場劣化推定技術の開発”、マツダ技報、 30 (2012) 219-223.

12) Y. Tomita, I. Shohji, S. Koyama and S. Shimizu: "Degradation behaviors of adhesion strength of structural adhesive for weldbonding under high temperature and humidity conditions", Procedia Engineering, 184 (2017) 231-237.

13) M. D. Placette, X. Fan, J.-H. Zhao and D. Edwards: "Dual stage modeling of moisture absorption and desorption in epoxy mold compounds", Microelectronics Reliability, 52 (2016) 1401-1408.

14) H. Shirangi, J. Auersperg, M. Koyuncu, H. Walter, W. H. Muller and B. Michel: "Characterization of dual-stage moisture diffusion, residual moisture content and hygroscopic swelling of epoxy molding compounds", Proc. of International conference on thermal, mechanical and multiphysics simulation and experiments in microelectronics and micro-systems (EuroSimE 2008), (2008) 1-8.

15) H. Shirangi, X. J. Fan and B. Michel: "Mechanism of moisture diffusion, hygroscopic swelling and adhesion degradation in epoxy mold compounds", Proc. of 41 st International symposium on microelectronics packaging (IMAPS), (2008) 917-923.

16) H. K. Yun, K. Cho, J. H. An and C. E. Park: "Adhesion improvement of copper/epoxy joints", Journal of Materials Science, 27 (1992) 5811-5817.

17) 栗原福：“プラスチックの劣化”、日刊工業新聞社、(1970) 76.

\section{代表者メールアドレス}

荘司郁夫 shohji@gunma-u.ac.jp 